\title{
Two Manuscript Comments by Early Readers in The Works of Mr John Marston (1633)
}

The copy of The Works of Mr John Marston (I633) in the collection of the Harry Ransom Humanities Research Centre at the University of Texas at Austin features two previously unknown manuscript comments. ${ }^{\mathrm{I}}$ The first comment dismisses Marston summarily as a tedious playwright, based on the first three plays in the volume - the comedy Antonio and Mellida, its tragic sequel Antonio's Revenge, and the tragedy Sophonisba. It states, 'Mr Iohn Marston. A very dull sencelesse Poett. I have read his 3 first Playes' (see figure I). The second comment is much kinder to the playwright; it praises his comedy Parasitaster, or The Fawn for being 'A good play' (figure 3). Both manuscript comments constitute rare records of early readers' response to Marston's plays and are valuable for several reasons. First, they are evidence for the conflicting reactions Marston's drama provoked in a family generally known for its theatrical enthusiasm. Second, the two comments are not broad or derived like other early readers' remarks on Marston's plays, especially those from the first century and a half since the publication of his Works. Instead they are the result of critical readings of concrete plays and are thus important for the rather limited history of Marston's early reception. Finally, the specific reference to Antonio's Revenge in the first comment is the only early one so far made upon an actual reading of the play.

The author of the first manuscript comment is Sir Richard Newdigate, Jr, a mining entrepreneur and landowner (I644-1710). ${ }^{2}$ His armorial bookplate, reading 'Sr Richard Newdigate, of Arbury in the County of Warwick, Baronet I709', is in the volume, and his handwriting in an account book entry of I7OI matches the handwriting of the comment too (figure 2). Identical graphemes can be seen in 'Iohn Marston' (line I, figure I) and 'Iohn King' (line I, figure 2); 'his' (line 3, figure I) and 'this' ('this County of Warwick', line 4, figure 2); 'first' (line 3, figure I) and 'still' ('is still Du', line ro, figure 2); and 'sencelesse' (line 2, figure I) and 'Witnesse' ('Witnesse my hand', line ıo, figure 2). 


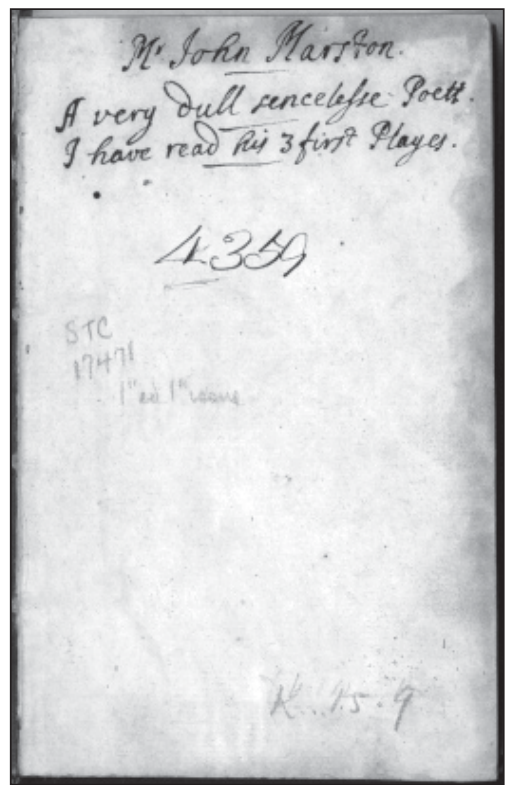

Fig. I. Recto side of first flyleaf of The Works of Mr John Marston (1633). By permission of the Harry Ransom Humanities Research Centre, The University of Texas at Austin.

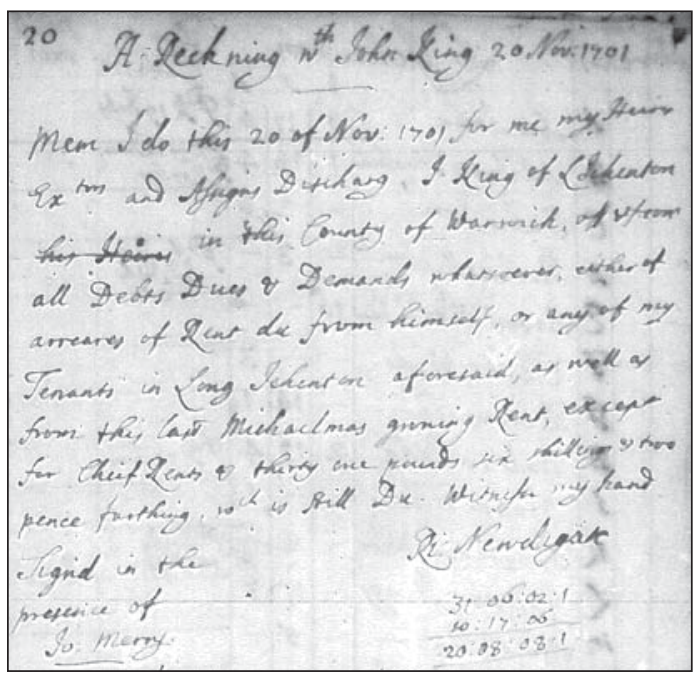

Fig. 2. Sir Richard Newdigate's account book entry of 20 November I70I, CRi36 / V23 / p. 20. By permission of Warwickshire County Record Office. 
Some letters in Sir Richard's account book, such as 'A' (line I, figure 2), 'd' in 'do' (line 2), 'f' in 'for' (line 2), and ' $\mathrm{y}$ ' in 'County' (line 4), may appear different from their counterparts in the Marston comment, but these differences are the result of variant forms. The 'A' in 'Assigns' (line 3, figure 2), the ' $\mathrm{d}$ ' in 'and' (line 3), the 'f' in 'aforesaid' (line 7), and the ' $y$ ' in 'any' (line 6) are all virtually identical with those in the Marston volume. The only mismatch is the ' $\mathrm{M}$ ' in 'Mr Iohn Marston' (line I, figure I) and 'Merry' (line I3, figure 2), but even in this case Sir Richard's ornamental stroke on his 'A' (line I, figure 2) is evident in both 'M's in the Marston volume.

Sir Richard's comment on Marston's plays can be dated tentatively between I678 and I709, as he most likely inherited the volume after his father's death on I4 October 1678 and passed away himself on 4 January I7IO. Whereas Sir Richard's identification as the author of the first comment has been straight forward, the identity of the person who wrote the second one remains a mystery. The handwriting suggests an earlier reader than Sir Richard, and can be dated approximately to the first twenty years after the publication of the volume in 1633 (figure 3). If Sir Richard did inherit the Marston edition from his father Sir Richard Newdigate, Sr (1602-78), then Sir Richard, Sr, would be the likeliest author of this second comment. ${ }^{3}$ The father put together an almost systematic playbook collection which he then passed on to his son.

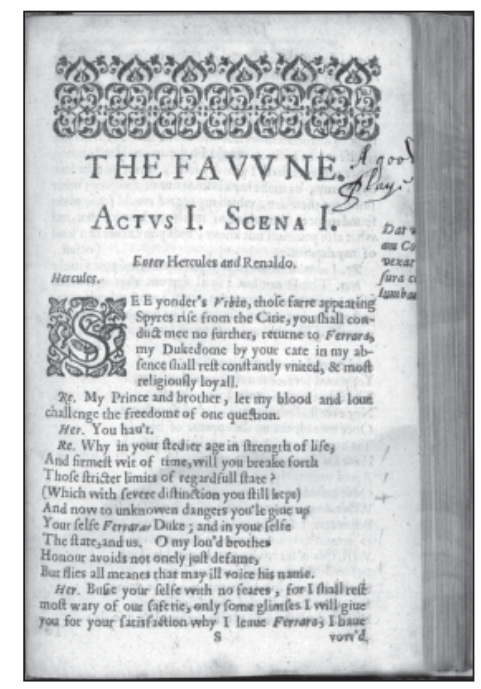

Fig. 3. Sig. Si of The Works of Mr John Marston (I633). By permission of the Harry Ransom Humanities Research Centre, The University of Texas at Austin. 
It remained part of the family library until the twentieth century when it was 'catalogued for sale on 22 January 1920, but was sold by private contract to G.D. Smith, of New York, from whom the choicest items passed to H.E Huntington'. ${ }^{4}$ Yet manuscript notes written by Sir Richard, Sr, on sermons in his possession have failed to produce a match. 5 His brother John Newdigate (1600-1642), another possible author, can be ruled out as well. ${ }^{6}$ John frequented the London theatres and purchased plays such as John Fletcher's The Scornful Lady, The Loyal Subject, The Faithful Shepherdess, John Ford's The Lover's Melancholy, and Ben Jonson's The New Inn. ${ }^{7}$ His autograph verse and letters, however, do not match the hand in the Marston volume either. ${ }^{8}$

The elusive author of the second comment was then perhaps a reader who had access to the Marston volume at the library of Sir Richard Newdigate, Sr. This person may have enjoyed the privileges of a literary friendship with Sir Richard, Sr, and his brother John, as they cultivated a few such acquaintances. The brothers were close friends of the future Restoration Archbishop of Canterbury Gilbert Sheldon (I598-1677).9 John bequeathed to Sheldon his collection of printed playbooks, and Richard paid Sheldon's bail when he was arrested by Cromwell's authorities. John also belonged to a literary circle under the patronage of the unconventional puritan Lady Jane Burdett (d. 1637), which included Sir George Gresley of Drakelowe (I580?-I65I) and her chaplain Thomas Calvert (I605/6-I679). Sir George's son Thomas (d. 1642) was a friend of John's from university and the husband of Lady Jane's daughter Bridget. ${ }^{\mathrm{IO}}$ John's commemorative verses on Lady Jane's death in I637 were published posthumously in The Weary Soul's Wish (1650), a volume featuring Calvert's funeral sermon and verses by Sir George and others. No evidence currently connects the anonymous comment on Marston's Parasitaster with Lady Jane, the Gresleys, or Calvert, and its handwriting does not match Sheldon's. II Its author however may have enjoyed a similar acquaintance with the Newdigate family. This anonymous reader appreciated Marston's Parasitaster most likely for its simple ridicule of courtly flattery, a target which was topical in the reigns of James I and Charles I. His or her praise for the play may also capture the spirit of a time Calvert would later remember fondly as 'full of feastings, Masks and Comedies'. ${ }^{12}$

Compared to the anonymous positive comment, the negative one left by Sir Richard Newdigate, Jr, is somewhat unexpected given the theatrical passion of his father and uncle. It may imply that drama was not Sir Richard's preferred choice of reading altogether. Besides the I633 edition of Marston's plays, he also owned a collected edition of Beaumont and Fletcher's plays, but 
that volume was curiously tucked 'in a chest of drawers along with five socks, two handkerchiefs, a pair of sleeves, and half shirt', an admittedly strange place to keep a valuable book. Instead, Sir Richard, Jr, enjoyed reading histories, travel literature, and most of all religious works. He owned Jeremy Taylor's manual on practical piety Rule and Exercises of Holy Living and Sir Mathew Hale's collection of short devotional essays Contemplations Moral and Divine, titles which he must have found useful in the context of his own daily devotions. ${ }^{13}$ His favourite bedtime books Relations of the World and the Religions Observed in All Ages and The History of Man by Samuel Purchas feature substantial religious history and commentary as well. ${ }^{14}$

While Marston's Antonio and Mellida, Antonio's Revenge, and Sophonisba are not without their own religious allusions, Sir Richard did not note any of them. Besides his possible dislike of drama, his criticism may also reflect the poor rendition of Marston's texts in the I633 edition and what he possibly perceived as Marston's 'sencelesse' lack of realism. His oversight in the case of the first play can be explained with the printer's omission of Marston's dedication in the collected edition (BI). The playwright had dedicated the I602 quarto to 'the most honorably renowned No-body', who is also 'religions shelter, and pieties fosterer'. I5 Yet Sir Richard's version of the text leaves out this sarcastic comment on the orphaned state of religion and piety. If printed, it would have appeared in the beginning of the volume and may have changed Sir Richard's opinion, but Sir Richard did not note the next religious allusion in Antonio and Mellida either. Here Feliche warns the tyrannical duke Piero that pride will eventually lead him to an impious conflict with God:

Shee'le make thee grudge to let Jehova share

In thy successefull battailes: $\mathrm{O}$, she's ominous,

Inticeth Princes to devoure heaven,

Swallow omnipotence, out-stare dread fate,

Subdue Eternitie in Giant thought.

The religious references in Marston's next two plays also failed to catch Sir Richard's attention. For example, in Antonio's Revenge Piero is again at his ungodly plots. He attempts to unite Venice, Florence, and Genoa in order to 'conquer Rome' and 'Pop out the light of bright religion' (H7v). In Sophonisba the protagonist opposes the idea that human transgression is predetermined by the gods; she believes that humanity alone is responsible for its trespasses. Yet the punctuation of her speech is confusing towards the end, a feature 
which may be another reason for Sir Richard's negative opinion of Marston's drama. Sophonisba states, 'Gods naught foresee, but see, for to their eyes / Naught is to come, or past, Nor are you vile, / Because the Gods foresee: for Gods not We, / See as things are things, are not, as we see' (Liv-L2). ${ }^{16}$ The intended meaning of the final two lines is perhaps 'for Gods and We / See as things are, things are not for we see'. In other words, things are not what they are because of how we and the Gods see them. The qualities of objects are not subject to external perception, and via association, humanity's sins are not the result of divine foreseeing or predestination.

However, even if Sir Richard did happen to notice Marston's religious allusions - despite the missing dedication to Antonio and Mellida and the confusing punctuation in Sophonisba - he probably would not have thought much of them anyway. His partiality to the more practical and matter-of-fact religious works of Purchas, Taylor, and Hale would have put him at odds with Marston's far less realistic drama. He may have thought the finale of Antonio and Mellida improbable, as the wanted duke Andrugio turns himself in only to claim the prize for his own head ( $\left.\mathrm{E}_{4}\right)$ ! The blood frenzy of Antonio's Revenge was likely to appal him too, especially as Antonio stabs the young child Julio under the roof of a church in order to take his revenge on the sinful flesh of the father Piero (HI). The witch Erichtho in Sophonisba may have seemed just as preposterous to him (M3v). Sir Richard probably did not know of Marston's career in the Church of England, but it would have made little difference if he did, as he preferred a more down-to-earth handling of the subject of religion. His manuscript comment is thus not only an interesting record of anti-dramatic sentiment in a family known for its dramatic enthusiasm but also evidence for the impact genre, style, and perhaps poor printing had on his perception of Marston's plays.

Besides revealing conflicting opinions of Marston's drama in the Newdigate family and their acquaintances, the two manuscript comments are also important because they are the result of early critical reading. In their engagement with specific play-texts, the comments resemble earlier references to Marston's drama such as Anthony Nixon's remarks on corruption in The Dutch Courtesan and satire in Eastward Ho; John Davies's mention of The Malcontent and Francis Beaumont's allusion to Parasitaster, both in conjunction to Marston's ordination as a minister; and Ben Jonson's observations of personal attacks and preachiness in Marston's comedies. To these could be added Aphra Behn's later creative adaptation of Marston's The Dutch Courtesan, which transforms Marston's villainous prostitute into a sympathetic 
character. ${ }^{17}$ The two manuscript comments however are unlike later remarks on Marston's plays, especially those made by readers in the first century and a half since the publication of his I633 collected edition. In this period only one commentator writes in a way that suggests serious engagement with Marston's play-texts, whereas the others resort to broad or derived statements which do not demonstrate convincing familiarity with his drama. William Sheares, the printer of the 1633 edition, seems to have set the tone for such remarks himself. In his dedication to Lady Elizabeth Cary, Viscountess Falkland (1585-1639), Sheares states that Marston is:

free from all obscene speeches, which is the chiefe cause that makes Playes to be so odious unto most men. He abhorres such Writers, and their Workes, and hath professed himselfe an enemie to all such as stuffe their Scenes with ribaldry, and lard their lines with scurrilous taunts and jests.

To this Sheares adds that Marston was 'not inferiour unto any in this kinde of Writing, in those dayes when these were penned, and I am perswaded equall unto the best Poets of our times' ( $\left.\mathrm{A}_{3} \mathrm{v}-\mathrm{A}_{4}\right)$. Sheares's general statements are thus less of an analysis of Marston's dramatic merits and more of a justification of his plays as literature worthy of a collected edition. Despite Marston's religious references, for example, Sheares neglects to explain some obvious exceptions to the playwright's clean language, such as the names of the pages in Antonio and Mellida, 'Catzo' and 'Dildo'. His claim to familiarity with Marston the person can be questioned too, as his publication of the playwright's works was unauthorised. Marston's name was removed from the title-pages of the volume, most likely through the influence of Marston's friend at the Stationers' Company, Henry Walley. ${ }^{18}$

The next unreliable early reference to Marston's drama comes from the 1675 survey Theatrum Poetarum Anglicanorum by Edward Phillips, John Milton's nephew. Phillips intended to bring out of obscurity the 'very many, especially of the writing party' who 'have fallen short of their deserved immortality of name, and lie under a total eclipse'. ${ }^{9}$ Yet his note on Marston's plays is not the product of independent reading but a convenient adaptation of Sheares's text above:

He was a chaste and pure writer, avoiding all that obscenity, ribaldry and scurrility which too many of the playwrights of that time, and indeed much more so 
in some periods since, have made the basis of their wit, to the great disgrace and scandal of the age: he abhorred such writers, and their works. ${ }^{20}$

Because of its dependence on Sheares's remark, Phillips's note does not reflect an actual reading of Marston's work, and offers little useful information or critical analysis besides the allusion to the state of drama since Marston's days.

In contrast to Phillips's statements, William Winstanley's evaluation of Marston seems independent, but his praise of the playwright is all too broad to determine whether he read any of Marston's plays. In his The Lives of the Most Famous English Poets (I687), this biographer praises Marston for being 'one whose fluent Pen both in a Comick and Tragick strain, made him to be esteemed one of the chiefest of our English Dramaticks, both for solid judgment, and pleasing variety'. ${ }^{21}$ Even if the vague reference to judgment and variety justifies Marston's inclusion in the group of those 'who in their Heroick Poems have made mens Fames live to eternity', Winstanley's praise does not offer a specific critical reading either. ${ }^{22}$

Similar questions can be raised even about Gerard Langbaine's Account of the English Dramatick Poets (I69I), although he is perhaps the only early commentator who read carefully most of Marston's dramatic texts. Langbaine identifies sources for The Dutch Courtesan, The Insatiate Countess, Parasitaster, Sophonisba, and What You Will and states that What You Will is 'one of our Authors best Plays'. ${ }^{23}$ His detailed examination of Marston's plays makes his assertions convincing, and his praise for What You Will is most likely in appreciation of the play's complex discussion of the immortality of the human soul and the instability of human identity. Yet Langbaine's claim that Marston's The Malcontent is 'an honest general Satyr and not (as some malicious Enemies endeavour'd to perswade the World) design'd to strike at any particular Persons' is not an independent opinion. ${ }^{24}$ It is instead an adaptation of the playwright's own address to the reader:

Yet in dispight of my indevors, I understand, some have beene most unadvisedly over-cunning, and with subtilitie (as deepe as hell) have maliciously spread ill rumours, which springing from themselves, might to themselves have heavily returned. ... [F] or the rest of my supposed tartnesse, I feare not, but unto every worthy minde it will be approved so generall and honest, as may modestly passe with the freedome of a Satyre. ${ }^{25}$ 
Langbaine's dependence on Marston's address therefore leaves doubts as to whether he actually read The Malcontent itself. His very brief mention of Antonio and Mellida and Antonio's Revenge also raises suspicions, as it includes no information to suggest he knew these two plays.

The antiquary Anthony Wood is another early commentator whose reference to Marston's plays does not presuppose actual reading. Wood's note on Marston, published in the first posthumous edition of his Athenae Oxoniensis (I72I), offers the observation that the playwright 'wrote divers things of great Ingenuity in the latter end of the Reign of Qu. Elizabeth, and beginning of K. James I'. ${ }^{26}$ Although Wood lists most of Marston's works, he does not make any specific critical remarks. Instead, he resorts to William Sheares's description of Marston's drama as 'free from all obscene speeches', but unlike Phillips, acknowledges most of his borrowing. ${ }^{27}$ Because of its broad and borrowed statements, however, Wood's note also fails to provide critical information on Marston's drama based on actual reading.

Finally, the compilation Lives of the Poets (1753), put together by Robert Shiels and other contributors, is yet another example of a derived early account of Marston's dramatic work. It offers a brief note on Marston which recycles both Langbaine's comment that What You Will is one of Marston's best plays and Langbaine's erroneous statement that eight of Marston's plays were acted at the Blackfriars theatre. ${ }^{28}$ In reality, only five of Marston's plays appeared at that venue, while another five may have been staged at Paul's, and a final one was presented at Whitefriars. A further error repeated here is Anthony Wood's mistaken assumption that William Shakespeare published Marston's 1633 edition instead of William Sheares. ${ }^{29}$ Like many of their predecessors, Shiels and his collaborators offer claims that are compromised by derivation or broad statements, which makes them unreliable in the reconstruction of Marston's early readings.

In contrast, the two manuscript comments in the volume of The Works of $\mathrm{Mr} J o h n$ Marston are indeed the result of early critical readings of concrete plays. Sir Richard's comment on Antonio and Mellida, Antonio's Revenge, and Sophonisba is an unlikely document of a reader with an apparent preference for non-dramatic literature confronting Marston's drama. It is also so far the only early reference to Antonio's Revenge made upon an actual reading of this play, as none of the other early commentators demonstrate a similar engagement with its text. Sir Richard's dismissal of Marston's three plays is possibly a reaction against their fantastic style and their poor rendition in Sheares's volume. His partiality to matter-of-fact devotional and historical religious 
prose may explain his negative comment and his failure to note Marston's own religious allusions. Unlike Sir Richard, the anonymous reader of Parasitaster was able to enjoy Marston's comedy. This person most likely knew Sir Richard's father and uncle and shared their theatrical passion. Marston's play may have earned his or her praise with its ridicule of inane court flattery, a popular satirical subject in the days of James I and Charles I.

\section{Notes}

My thanks to Dr Elizabeth Harvey for her patient encouragement and to the editor and readers at Early Theatre for their helpful comments.

John Marston, The Works of Mr John Marston being tragedies and comedies collected into one volume (London, 1633).

2 Vivienne Larminie, 'Newdigate, Sir Richard, second baronet (1644-1710)', Oxford Dictionary of National Biography (Oxford, 2004), hereafter cited as ODNB, URL:<http:// www.oxforddnb.com/view/article/4796r>, 4 November 2008.

3 Vivienne Larminie, 'Newdigate, Sir Richard, first baronet (I602-I678)', ODNB, URL:<http://www.oxforddnb.com/view/article/20002>, 6 November 2008.

4 Seymour De Ricci, English Collectors of Books and Manuscripts (I530-1930) and Their Marks of Ownership, (New York, 1930, rpt 1969), I88-9.

5 Amanda Williams (Warwickshire Record Office), E-mail to the author, 9 May 2008.

6 Vivienne Larminie, 'Newdigate, John (I600-I642)', ODNB, URL:<http://www. oxforddnb.com/view/article/52766>, 4 November 2008.

7 Vivienne Larminie, Wealth, Kinship, and Culture: The Seventeenth-Century Newdigates of Arbury and Their World (Woodbridge, Suffolk, I995), 20I-5.

8 G.M.D. Booth (Warwickshire Record Office), Email to the author, 9 January 2006.

9 John Spurr, 'Sheldon, Gilbert (1598-1677)', ODNB, URL:<http://www.oxforddnb. com /view/article/25304>, 6 November 2008.

Io Vivienne Larminie, 'Burdett, Jane, Lady Burdett (d. I637)', ODNB, URL:<http:// www.oxforddnb.com/view/article/67232>, I7 January 2009. Claire Cross, 'Calvert, Thomas (1605/6-1679)', ODNB, URL:<http://www.oxforddnb.com/view/ article/4427>, I7 January 2009.

II Mark Smith (Derbyshire Record Office), Email to the Author, 20 January 2009. Mike Webb (Bodleian Library, Western MSS), E-mail to the author, 22 December 2008.

I2 Thomas Calvert, The Weary Soul's Wish (1650), 4.

I3 Eileen Gooder, The Squire of Arbury: Sir Richard Newdigate, Second Baronet (I644I710) and His Family (Coventry, 1990), 25. 
I4 Ibid, 57-8.

I5 John Marston, The History of Antonio and Mellida (London, I602), A2.

I6 The I606 quarto is not clear either: 'Gods naught foresee, but see, for to their eyes I Naught is to come, or past, Nor are you vile / Because the Gods foresee: for Gods and We / See as things are things are not, for we see' (C2v).

I7 Anthony Nixon, The Black Year (London, I606), B2. John Davies, Scourge of Folly (London, I6ro), I05. F[rancis] B[eaumont], 'To Mr B: J:', William Shakespeare: A Study of Facts and Problems (Oxford, 1930), 222-5. Ben Jonson, 'Conversations with Drummond', Ben Jonson, C.H. Herford and Percy Simpson (eds) (Oxford, I925), I38, I40. Aphra Behn, The Revenge, or a Match at Newgate (London, I680).

I8 Philip J. Finkelpearl, 'Henry Walley of the Stationers' Company and John Marston', Papers of the Bibliographical Society of America 56 (1962), 366-8.

I9 Edward Phillips, Theatrum Poetarum Anglicanorum (London, I675), xiii.

20 Ibid, 234.

2I William Winstanley, The Lives of the Most Famous English Poets (London, I687), I37.

22 Ibid, Preface to the Reader, A4v.

23 Gerard Langbaine, An Account of the English Dramatick Poets (Oxford, I69I), 35I.

24 Ibid, 350.

25 John Marston, The Malcontent (London, I604), A2.

26 Anthony Wood, Athenae Oxoniensis, vol I (London, I72I), 332.

27 Ibid, 333.

28 Robert Shiels, Lives of the Poets, vol I (London, I753), I2O.

29 Ibid. 